\title{
Reconnecting Finance and the Good Society
}

\section{HOW A LEADERSHIP PROGRAM AIMS TO SHAPE A MORE TRUSTWORTHY INDUSTRY}

By Allison Adams

Since the launch of the Future of Finance initiative, CFA Institute has sought to empower the world of finance to create an environment where investor interests come first, markets function at their best, and economies grow. Local societies and CFA Institute members have played a critical role in this global effort to shape a trustworthy, forward-thinking financial industry that better serves society.

This focus comes naturally for Ranji Nagaswami, CFA, a 30-year veteran of the investment management industry. After leaving the private sector, she helped to manage New York City's $\$ 120$ billion employee retirement system under Mayor Michael Bloomberg's administration. She saw her role evolve from a successful investment management professional to someone who also wanted to "build something that would endure." Her involvement in the Henry Crown Fellowship Program at the Aspen Institute (which seeks to develop the next generation of community-spirited leaders) reinforced those beliefs. As she puts it, "Are you going to be an active, engaged leader in society, or are you going to be a bystander, so absorbed in building your company that you don't find the time or the impetus to engage in society?"

In a recent interview (which can be viewed in full at http://cfa.is/1qodtT7) with Allison Adams, head of content engagement and publishing at CFA Institute, Nagaswami, a senior adviser and operating partner at Corsair Capital, discussed why she helped launch the Aspen Institute Finance Leaders Fellowship Program with support from CFA Institute, as well as the importance of finance and society remaining connected to enable positive outcomes.

\section{Why are you and the Aspen Institute launching the Finance Leaders Fellowship Program at this time?}

The need for the Finance Leaders
Fellowship Program really crystallized for me in the time that I spent in the Bloomberg administration. A few things became very clear to me in that period. The first was the central role of finance in shaping a better outcome for society. Yale Professor and Nobel Laureate Robert Shiller (a member of the CFA Institute Future of Finance Advisory Council) often has spoken about finance as the engine that drives the good society, and I completely agree with this view in the pension context. Pensions are essentially social contracts, and we agree-employers and employees-to set aside money today for the benefit of employees in their retirement years when they no longer have labor income. But the great enabler between the present and the future are returns generated on those contributions today that reduce the cost and the burden and improve outcomes for retirees down the road. So, finance and its many innovations-pensions, insurance, mortgages, savings accounts, and others-have all inherently changed the way we live and work in society, and my work in the Bloomberg administration really reinforced that core belief.

It also became very clear to me that while finance had this great ability to solve problems in society, the ability of some actors in finance to create massively negative outcomes-episodic crashes in the market because of the actions of a few-has really disenfranchised many in society from the industry. More and more, finance has become viewed as something that the financiers engage in for finance itself rather than for the good of society.

And so, for all of these reasons, I approached Aspen Institute to think about a leadership program, which at its core has this belief that leaders who are responsible for great businesses could also lead in terms of social change and taking the lead on societal issues for the greater good.

\section{You have been involved with both the Aspen Institute and CFA Institute for many years. How do you bridge between the Aspen Institute's mission for the Finance Leaders Fellowship Program and the mission of CFA Institute?}

There's a tremendous synergy, not just in the mission but also in the core beliefs that are at the heart of the Finance Leaders Fellowship Program. The mission of the Finance Leaders Fellowship Program is to create a generation of leaders who really see it as their responsibility to create more positive connections between finance and society. The mission of CFA Institute is not very different. It is the organization that sets the standards for the investment management industry. It is the organization that really wants the CFA charterholders to use the charter, to use their professional designation, in ways that help improve and shape society. So, the mission synergies are actually very obvious.

But there is more than that. There is a set of beliefs that are at the heart of the Finance Leaders Fellowship Program that found great resonance among the leadership of CFA Institute. First, a firm belief that it is the individual who needs to lead. It is leaders who shape change in society. For CFA Institute, think of the entire organization-not just your senior and professional colleagues around the world who work at CFA Institute, but the many who lead the local societies, the volunteers who administer and then check the exams, and the many leaders who engage between their local chapters and their local industry. So, the common goal is connecting the investment management industry to society and connecting the finance fellows who accept responsibility for shaping the society and who have at their foundation this belief in leadership as the way to change and shape an industry in a society. 


\section{How will the program make a difference in finance, specifically the investment management profession?}

All of us engaged in launching the Finance Leaders Fellowship Program really have the core belief that finance is the engine that drives the good society. And, fundamentally, we want to use this fellowship as a way to bring the industry's more thoughtful, successful leaders together across the finance ecosystem in this conversation about how to reconnect finance and the good society.

We all agree that there are innovations in finance that are messy, that are disruptive. We agree that, episodically, finance has not added value for society and has, in fact, shown a tendency to potentially take society to the brink. But the enduring value of finance is fundamentally evident in innovations like pensions, insurance, savings accounts, and mortgages.
For finance to succeed, we need a finance industry that is led by enlightened leaders who accept as their responsibility the connection between finance and society, who see it as their mandate to nudge the industry's innovations towards problem solving that helps society-not just in the short run, but also in the long run. I daresay that without this enlightened leadership, I am less confident that finance will not be more and more for finance itself. When you think about the investment management profession, which at its core has

\section{KEEP GOING}

Aspen Institute Finance Leaders Fellowship Program: aspeninstitute.org/flf

CFA Institute Future of Finance initiative: cfainstitute.org/learning/future

"New Fellowship Program for Financial Leaders," CFA Institute Magazine (March 2016) [www.cfapubs.org] agents who are fiduciaries managing assets on behalf of retirees (whose main mission, if they are successful, is generating high risk-adjusted returns that could fundamentally alter life outcomes for retirees), that alignment between what investment management is here to do and society is sometimes lost.

In the Finance Leaders Fellowship Program, we strive to develop a far deeper understanding of the role that investment managers and other intermediaries play in society. By moderating a conversation across the industry ecosystem about values such as a leader's life purpose and responsibility for action-our responsibility as leaders to build the good society-this fellowship has a chance, over time, of being one of the many ways to strengthen the connection between finance and society.

Allison Adams is head of content engagement and publishing at CFA Institute.

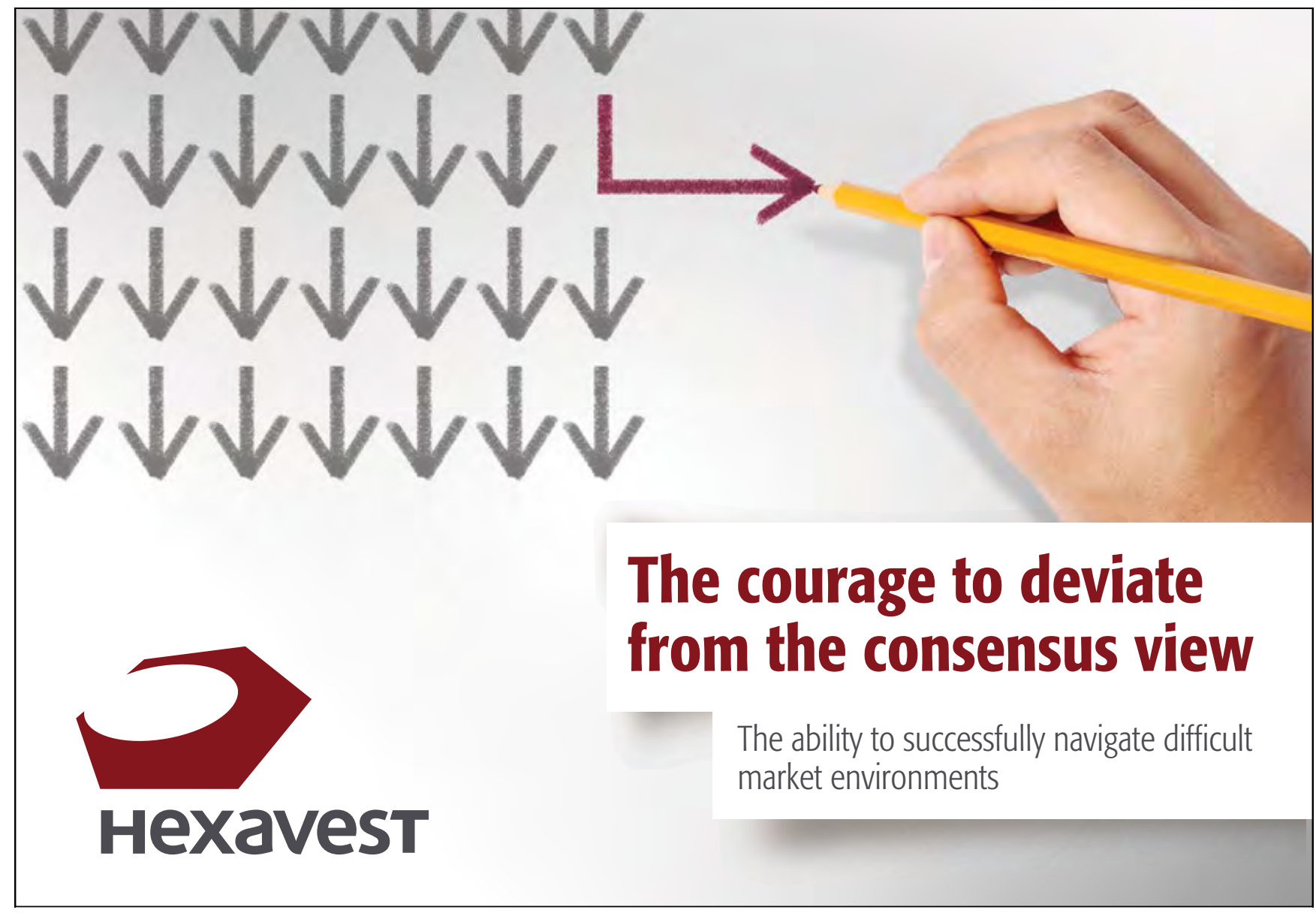

